\title{
Consanguineous Marriage, Reproductive Behaviour and Postnatal Mortality in Contemporary Iran
}

\author{
Meimanat Hosseini-Chavoshi ${ }^{a}$ Mohammad J. Abbasi-Shavazi ${ }^{a, b}$ \\ Alan H. Bittles ${ }^{c, d}$ \\ ${ }^{a}$ Crawford School of Public Policy, Australian National University, Canberra, A.C.T., Australia; ${ }^{b}$ Department of \\ Demography, University of Tehran, Tehran, Iran; ${ }^{C}$ Centre for Comparative Genomics, Murdoch University, and \\ ${ }^{\mathrm{d} S}$ School of Medical Sciences, Edith Cowan University, Perth, W.A., Australia
}

\section{Key Words}

Consanguinity · Population stratification · Reproductive behaviour · Prenatal loss · Postnatal mortality · Genetic disorders $\cdot$ Iran

\begin{abstract}
Objectives: The aims of the study were to determine the prevalence, types and socio-economic correlates of consanguineous marriages in Iran, and to gauge the extent to which consanguinity influenced fertility, pregnancy outcomes and the expression of genetic disorders in the present-day population. Methods: Data on the prevalence of consanguinity and birth outcomes in the first marriages of 5,515 women were abstracted from the 2005 Iran Low Fertility Study [Hosseini-Chavoshi et al: Fertility and Contraceptive Use Dynamics in Iran: Special Focus on Low Fertility Regions. Canberra, Australian National University, 2007]. The results of associated socio-economic variables were collated and assessed by Pearson's $X^{2}$ analysis and logistic regression. Results: Overall, $37.4 \%$ of the marriages were consanguineous ( $a=$ 0.0149), but with major differences between 4 representative populations. Consanguinity was higher among rural couples, older marriage cohorts, women marrying at a
\end{abstract}

younger age, and women with lower levels of formal education. In general, consanguineous couples had higher mean numbers of pregnancies, live births and surviving children. Conclusions: Given declining family sizes, a rapid urbanization and increased educational and employment opportunities, it seems inevitable that consanguineous marriages will decline in prevalence in Iran, albeit more slowly in more traditional rural communities. Predictably, there will be a concomitant reduction in the incidence of recessive genetic disorders, but this is against a background transition from communicable to non-communicable diseases.

(c) 2014 S. Karger AG, Basel

\section{Introduction}

In common with many human populations $[1,2]$, consanguineous marriage has long been the culturally preferred form of marital union in Iran [3-6]. While the preference for close-kin marriage markedly declined during past generations in Europe, North America, Oceania and East Asia, the tradition of intra-familial unions has largely continued in Iran and other countries of the Middle East, Central and South Asia [2,7]. Nevertheless, in some

\section{KARGER}

E-Mail karger@karger.com

www.karger.com/hhe (c) 2014 S. Karger AG, Base

$0001-5652 / 14 / 0774-0016 \$ 39.50 / 0$
Dr. Meimanat Hosseini-Chavoshi

Australian Demographic and Social Research Institute

Australian National University

Canberra, ACT 0200 (Australia)

E-Mail meimanat.hosseini@anu.edu.au 
countries of the region, including Lebanon, Saudi Arabia, Kuwait, Jordan, and the Palestinian Territories, there appears to have been a quite recent shift away from close-kin unions with a reduction in first-cousin marriages in particular [8-12].

The modern history of Iran has been turbulent, with the 1979 Islamic Revolution rapidly followed by a prolonged war with neighbouring Iraq from 1980 to 1988, in which up to $1,000,000$ Iranian casualties were incurred [13]. The prevalence of consanguineous marriages increased in Iran from the 1940s to the 1970s [14, 15], and this pattern continued during the immediate postRevolution phase of the early 1980s $[15,16]$. The trend gradually reversed from the mid-1980s onwards, following an increased urbanization and greater access to secondary and tertiary education for both males and females. However, even at the beginning of the 21 st century around $40 \%$ of all marriages were still contracted between couples related as second cousins or closer $(F \geq$ $0.0156)$ [16].

This composite figure can be misleading, given the major ethnic and religious divisions within the country $[3,17,18]$, as the prevalence of consanguineous and endogamous marriages varies greatly between communities: i.e. from $2.8 \%$ consanguinity, which is equivalent to a mean coefficient of inbreeding ( $\alpha$ ) of 0.0018 in the Christian Armenian community, to $52.1 \%(\alpha=0.0289)$ in the minority Sunni Persian community and 50.0\% ( $\alpha=$ 0.0294) among the Baluchi, who are also Sunni Muslims and live in the largely tribal province of Sistan-Baluchistan, which is adjoining Afghanistan and Pakistan [3, 1620].

The initial motive for the present study was to examine the prevalence of consanguineous marriages in 4 representative regions of Iran and to investigate whether the downward trend in consanguinity, established in the late 20th century, had continued. More importantly, in the context of this special issue of Human Heredity, we also wished to examine the patterns and determinants of reproductive behaviour in the present-day Iranian society and to identify how these factors could influence the prevalence and distribution patterns of genetic diseases.

\section{Subjects and Methods}

The Islamic Republic of Iran is a large country, comprising some 1.65 million $\mathrm{km}^{2}$, situated at the cross-roads of many ancient trade routes. In religious terms, approximately $99 \%$ of the population is Muslim, predominantly Shia, with numerically small Zoro-
Table 1. Marital relationships in the 2005 Iran Low Fertility Survey

\begin{tabular}{llc}
\hline Spousal relationship & $F, a$ & Couples \\
\hline First cousin ${ }^{1}$ & 0.0625 & \\
$\quad$ Sub-type I & & $307(5.6 \%)$ \\
$\quad$ Sub-type II & & $295(5.3 \%)$ \\
$\quad$ Sub-type III & & $275(5.0 \%)$ \\
$\quad$ Sub-type IV & & $185(3.4 \%)$ \\
$\quad$ All first-cousin sub-types & \multirow{2}{*}{0.0156} & $1,062(19.3 \%)$ \\
Second cousin & 0 & $3,000(18.1 \%)$ \\
Unrelated & & $5,515(62.6 \%)$ \\
\hline Couples sampled & & 11 \\
Incomplete data & & 5,526 \\
All couples & & \\
\hline
\end{tabular}

$F=$ Coefficient of inbreeding.

${ }^{1}$ Parallel first-cousin marriages of sub-type I are to father's brother's daughter; those of sub-type II are to mother's sister's daughter. Cross first-cousin marriages of sub-type III are to father's sister's daughter; those of sub-type IV are to mother's brother's daughter.

astrian, Christian and Jewish minorities. As a result of its history and geographical location, the current population of 75 million [21] is ethnically heterogeneous. Just under $50 \%$ of the national population is Persian, with the remaining approximately $50 \%$ comprising a wide range of distinct ethnicities including Arab, Armenian, Assyrian, Azari, Bakhtiari, Baluchi, Kurdish, Qashqai, Turkmen and Zaboli communities [3, 17, 18].

Iran is a middle-income country, with a reported infant mortality rate of 21/1,000 [22] and mean life expectancies for men and women of 72 and 74 years, respectively [21]. A study conducted by the March of Dimes in 2002 indicated a national birth defect rate of $64.5 / 1,000$, equivalent to 103,000 birth defects annually [23], and in 2008 an estimated $72 \%$ of all deaths were ascribed to noncommunicable diseases [24].

The primary data set used for the study was the 2005 Iran Low Fertility Survey [25] with information abstracted for 4 study populations: the province of Gilan in the north of the country which adjoins the Caspian Sea and has a population of 2.4 million, the provinces of Ishafan and Yazd in central-southern Iran with populations of 4.9 and 1.0 million, respectively, and Tehran, the national capital, which has a population of 12.1 million (fig. 1). Collectively, these 4 populations enjoy a high socio-economic status and they are representative of the low-fertility provinces in Iran $[20,25]$.

Using systematic random sampling, 7,350 households were initially contacted for the permission to conduct face-to-face interviews with ever-married women aged 15-54 years, to determine their attitudes towards reproduction and reproductive practices. A total of 5,526 ever-married women were recruited for the Survey, but in 11 cases the information obtained was incomplete, giving a total sample for analysis of 5,515 women. The data collection was conducted according to a coded questionnaire and a complementary study manual by trained interviewers with tertiary qualifications either as midwives or family health officers [25]. 


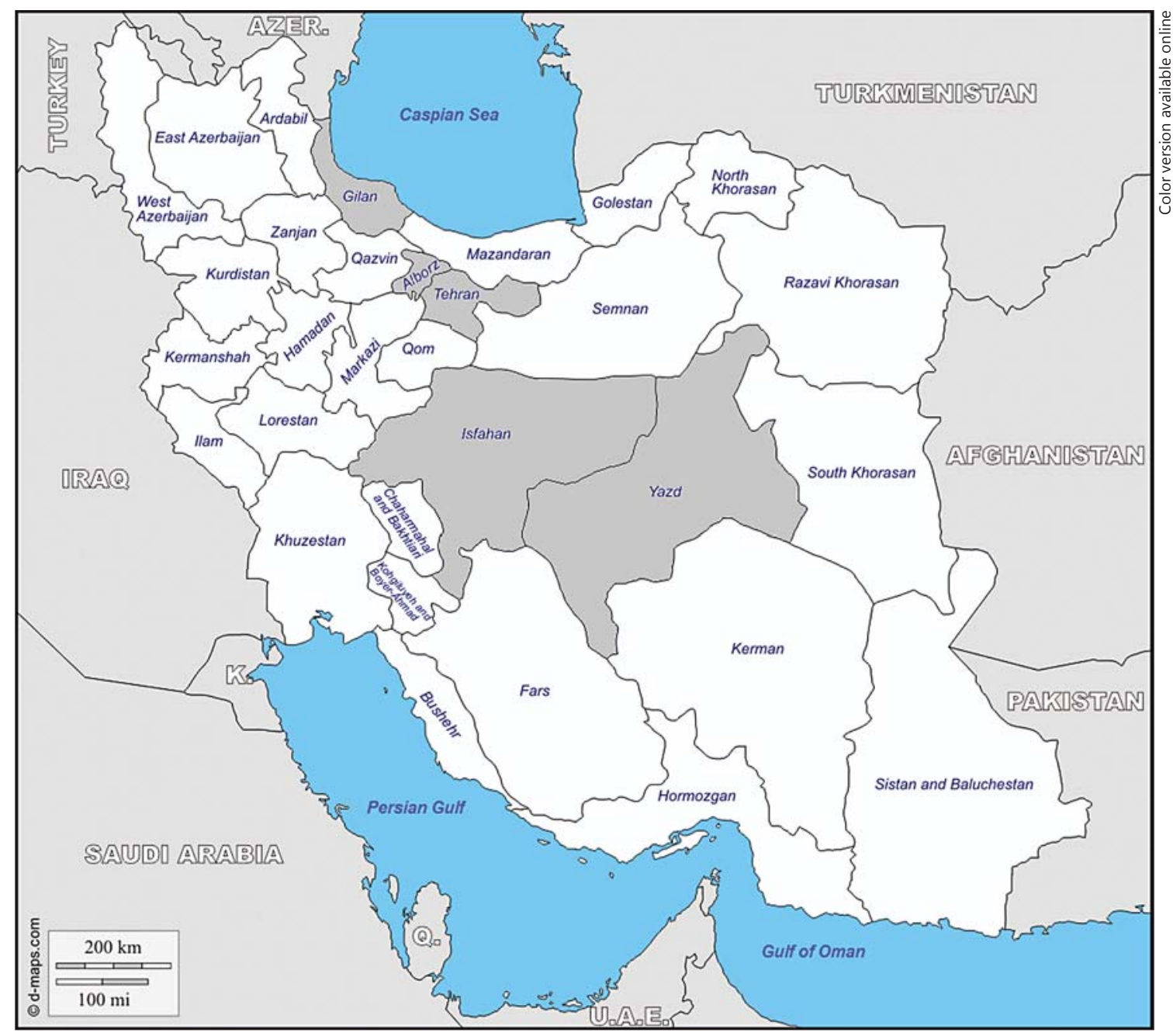

Fig. 1. Provincial data collection sites (in dark grey) in Iran in 2005. The sites of the study included all areas in the 3 provinces of Gilan, Isfahan and Yazd plus the capital city of Tehran in Tehran province. At the time of data collection in 2005, Alborz was part of Tehran province.

A part of the study information was collected from the subjects on their spousal relationship, whether they were first cousins, including the specific sub-type $(F=0.0625)$, second cousins $(F=$ $0.0156)$ or unrelated $(F=0$; table 1$)$. At the same time, data was also collected on a range of socio-demographic variables: i.e. the province of residence, urban or rural domicile, maternal age, year of marriage, highest education level, number of pregnancies, number of live-born children and number of surviving offspring (table 2).

Using the IBM SPSS Statistics 20 software package, Pearson's $\chi^{2}$ test was conducted on the socio-demographic variables examined, with the results assessed for statistical significance by either Phi and Cramer's V test or Pearson's R, depending on the nature of each variable. A logistic regression analysis was then applied to the data to test the odds ratios of consanguineous marriages for each demographic characteristic, while controlling for other demographic characteristics included in the model.

\section{Results}

\section{Prevalence of Consanguineous Marriages}

Data on the prevalence and types of consanguineous marriages are presented in table 1 . Across the 4 study settings, $37.4 \%$ of all marriages were consanguineous, comprising first-cousin (19.3\%) or second-cousin (18.1\%) unions, which is equivalent to a mean coefficient of inbreeding ( $\alpha$ ) of 0.0149 . Contrary to the custom in neighbouring Arab countries, where a large majority of firstcousin marriages are preferentially contracted between a man and his father's brother's daughter [12, 26, 27], socio-cultural influences in Iran mean that all 4 types of parallel and cross first-cousin marriages are freely per- 
Table 2. Consanguineous marriages by socio-demographic characteristics in the 2005 Iran Low Fertility Survey

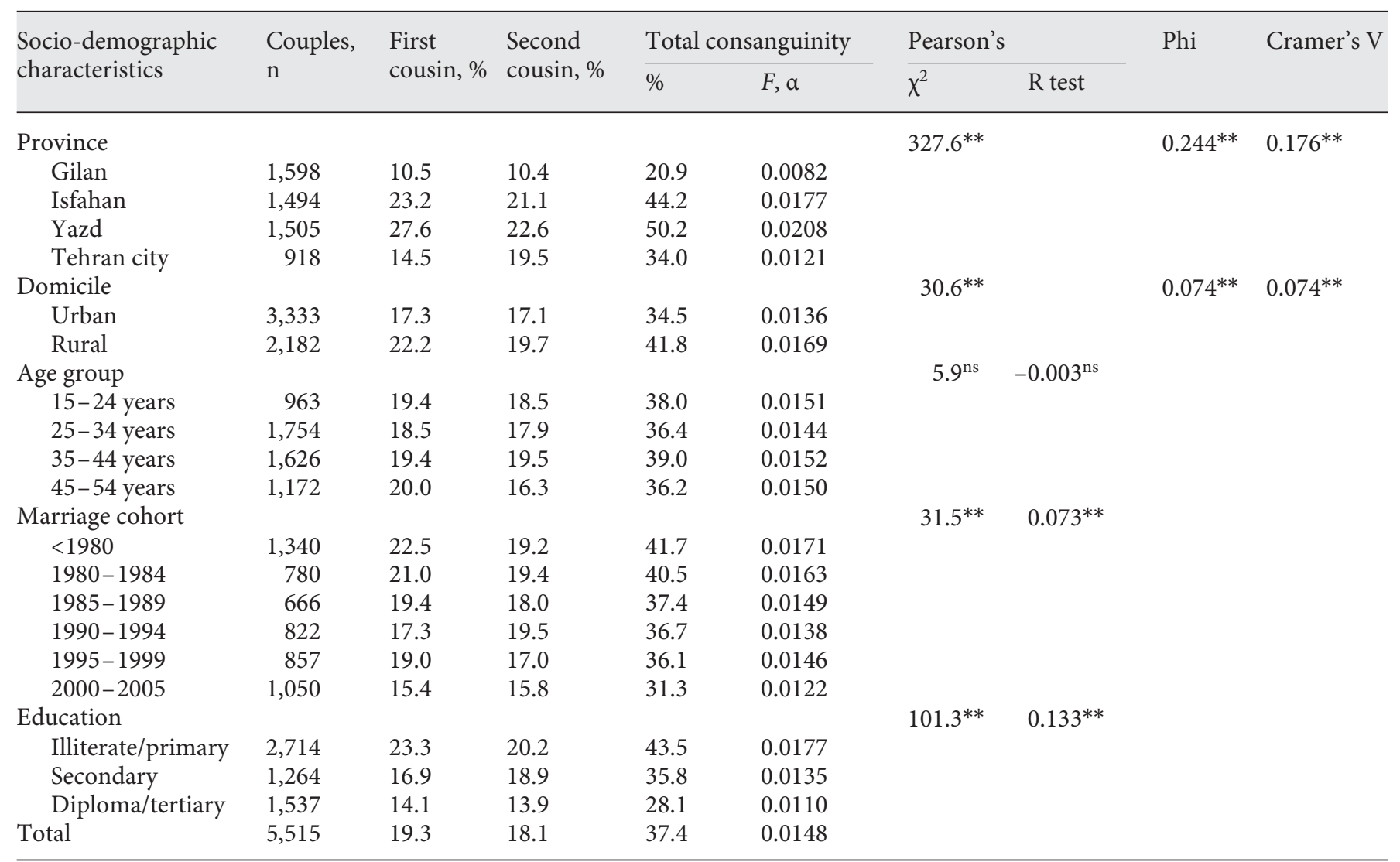

$F, \alpha=$ Mean coefficients of inbreeding.

ns $=$ Not significant; ${ }^{* *} \mathrm{p}<0.01$.

missible $[3,6,14]$, as reflected in the results of the present study (table 1).

The individual results for the mean levels of spousal consanguinity in the 4 study centres varied significantly $(\mathrm{p}<0.01)$ : from $20.9 \%$ consanguineous marriages $(\alpha=$ 0.0082 ) in the northern province of Gilan to $50.2 \%$ consanguinity $(\alpha=0.0208)$ in the central-southern province of Yazd (table 2). There was also a significant difference in the profile of consanguineous unions: with the highest ratio of first-cousin:second-cousin marriages in Yazd (1.22) and the lowest in Tehran city (0.74), suggesting a significantly stronger preference for firstcousin marriages in Yazd. Within Iran, Yazd is regarded as a conservative province whose residents place a greater emphasis on traditional aspects of family life resulting, for example, in the lowest divorce rate in the country [28].

Reproductive and Health Outcomes of Consanguinity in Iran
The Influence of Socio-Demographic Variables on Consanguinity

An analysis of the socio-demographic variables showed that $60.4 \%$ of the women interviewed lived in an urban environment and $39.6 \%$ had a rural domicile (table 2). As consistently reported from other countries in the Middle East and South Asia [29-31], the prevalence of consanguineous marriages was higher among rural residents $(41.8 \%, \alpha=0.0168)$ than among their urban counterparts (34.5\%, $\alpha=0.0136)$.

Somewhat surprisingly, female age appeared to exert no significant effect on either the percentage of spousal consanguinity or the mean coefficient of inbreeding. This contrasted with the results by marriage cohorts, which showed a consistent significant decline in both the mean percentage of spousal consanguinity and the mean coefficient of inbreeding: from $41.7 \%$ consanguineous marriages $(\alpha=0.0171$ ) before 1980 to $31.3 \%$ consanguinity 
Fig. 2. Consanguinity and mean ages (in years) at marriage, first pregnancy and second pregnancy by marriage cohort.

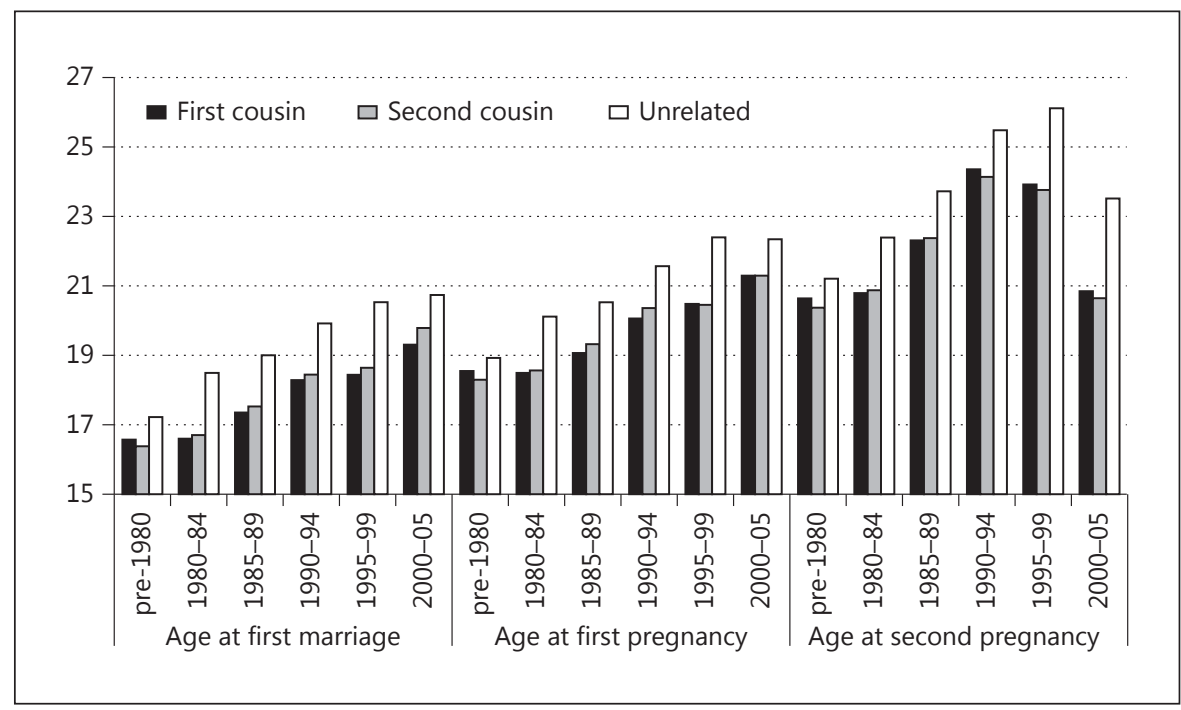

$(\alpha=0.0122)$ in the $2000-2005$ cohort $(p<0.01)$. However, when female age at the first marriage, instead of current age, was included in the logistic regression model, the results revealed that the rate of consanguineous marriages had not significantly changed over time. In fact, marriage at younger female ages was the factor that explained the apparent higher probability of consanguineous marriages by marriage cohorts.

The data on female education also were consistent with other studies conducted in the region [30,32-34], with the lowest prevalence of consanguineous marriages among women who had obtained a diploma or undertaken tertiary studies $(28.1 \%, \alpha=0.0110)$ versus $43.5 \%$ consanguinity ( $\alpha=0.0177)$ in women who were illiterate or had only been enrolled in primary-level education $(\mathrm{p}<0.01)$.

\section{Consanguinity and Reproductive Behaviour}

Information on the influence of consanguinity on the mean female age at first marriage very clearly indicated that, with the exception of the pre-1980 cohort, first cousins married youngest, followed by couples related as second cousins and with couples who were unrelated marrying at a comparatively older age (fig. 2). The mean age difference between the 3 consanguinity categories was lowest in the pre-1980 cohort (first cousins: 16.6 years; second cousins: 16.4 years, and unrelated: 17.3 years) and highest in the 1995-1999 cohort (first cousins: 18.5 years; second cousins: 18.7 years, and unrelated: 20.5 years). More generally, there was a highly significant temporal increase in the mean age at marriage $(\mathrm{p}<0.01)$ across all 3 consanguinity categories.
Not surprisingly, the relationship between consanguinity and female age at first pregnancy largely followed that observed with age at first marriage, with unrelated couples consistently reporting the highest mean age at first pregnancy (fig. 2). Across all marriage cohorts, the difference in mean age at first pregnancy between firstand second-cousin couples was, however, less obvious than for age at first marriage, suggesting a possible delay in the age at which the younger first-cousin couples successfully initiated reproduction.

A mixed picture emerged with respect to maternal age at second pregnancy, which increased across all 3 consanguinity categories up to and including the 1995-1999 cohort but then declined during 2000-2005. This is in keeping with the limited opportunities to initiate a second pregnancy during the five-year period prior to the time of data collection in 2005. In the pre-1980 to 1995-1999 marriage cohorts, the pattern of maternal age at second pregnancy closely matched that observed with first pregnancies: with essentially similar results obtained with first- and second-cousin couples, and unrelated couples reproducing at an older mean age for the second time.

\section{Consanguinity, Total Number of Pregnancies, and}

\section{Pre- and Postnatal Losses}

With the exception of the 2000-2005 marriage cohort in which, as noted above, reproduction was effectively truncated by the timing of the Survey (conducted in 2005), first- and second-cousin couples had a higher mean number of pregnancies than unrelated spouses (fig. 3). This pattern was generally replicated with respect to the mean 
Fig. 3. Consanguinity and the mean total numbers of pregnancies, children ever born and surviving offspring by marriage cohort.

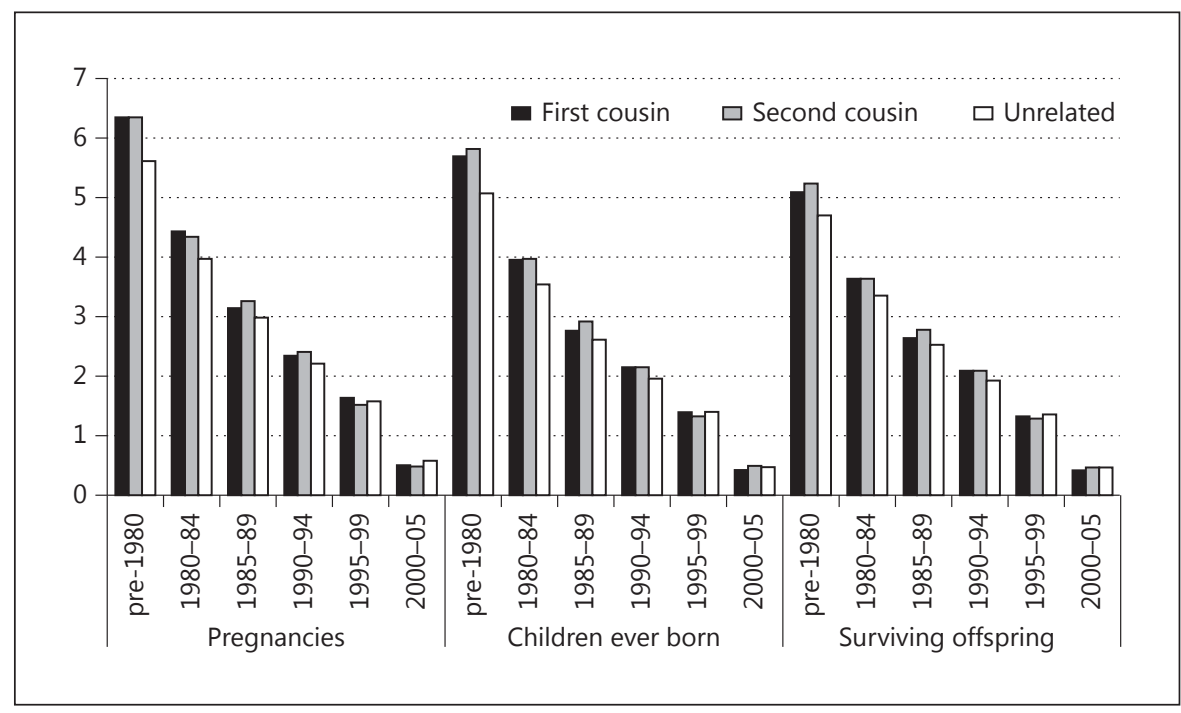

Table 3. Consanguinity, mean percentage prenatal losses and postnatal mortality by marriage cohort in the 2005 Iran Low Fertility Survey

\begin{tabular}{|c|c|c|c|c|c|c|}
\hline \multirow{2}{*}{$\begin{array}{l}\text { Marriage } \\
\text { cohort }\end{array}$} & \multicolumn{3}{|c|}{ Prenatal losses, $\%^{1}$} & \multicolumn{3}{|c|}{ Postnatal deaths, $\%^{2}$} \\
\hline & $\begin{array}{l}\text { first } \\
\text { cousin }\end{array}$ & $\begin{array}{l}\text { second } \\
\text { cousin }\end{array}$ & unrelated & $\begin{array}{l}\text { first } \\
\text { cousin }\end{array}$ & $\begin{array}{l}\text { second } \\
\text { cousin }\end{array}$ & unrelated \\
\hline$<1980$ & 12.1 & 9.8 & 11.5 & 11.9 & 11.3 & 7.8 \\
\hline $1980-1984$ & 12.6 & 10.7 & 12.4 & 9.1 & 8.7 & 5.2 \\
\hline $1985-1989$ & 14.2 & 12.8 & 14.9 & 5.3 & 5.1 & 3.3 \\
\hline $1990-1994$ & 11.2 & 14.5 & 14.0 & 2.0 & 2.4 & 2.1 \\
\hline $1995-1999$ & 19.1 & 16.8 & 14.3 & 5.0 & 1.6 & 3.4 \\
\hline $2000-2005$ & 17.1 & 7.1 & 21.4 & 1.3 & 1.2 & 1.7 \\
\hline
\end{tabular}

${ }^{1}$ Calculated as mean number of pregnancy losses divided by mean number of children ever born.

${ }^{2}$ Calculated as mean number of postnatal deaths divided by mean number of surviving offspring.

number of children ever born and the mean number of surviving offspring, although unrelated spouses in the 1995-1999 cohort reported a slightly higher mean number of live-born offspring $(\mathrm{n}=1.42)$ than first-cousin $(\mathrm{n}=$ 1.34 ) or second-cousin couples ( $\mathrm{n}=1.41$; fig. 3 ).

The influence of consanguinity on the mean number of pre- and postnatal losses is summarized in table 3. At first sight, there appeared to be a temporal increase in prenatal losses across all 3 consanguinity categories, but it is probable that this observation, as will be discussed later, mainly reflected problems in maternal recall of abortions/miscarriages. However, as previously reported across a range of populations [2], there was no convincing evidence for a significant consanguinity-associated increase in prenatal losses.

The situation was different for postnatal deaths in the pre-1980, 1980-1984 and 1985-1989 marriage cohorts (table 3). In each of these cohorts, the mean postnatal mortality was higher in the progeny of consanguineous parents, and the percentage of deaths was greater among first-cousin $(F=0.0625)$ than among second-cousin offspring $(F=0.0156)$, which is consistent with adverse consanguinity-associated health outcomes due to the expression of recessive disease genes. As the number of live-born children and the timing of the reporting period reduced, the differentials between the mean survival among firstcousin, second-cousin and unrelated progeny diminished or disappeared. From a population genetics perspective, this finding is in keeping with the theoretical expectation that the larger the family size, the greater the probability that at least one affected child will be born to parents who both are carriers of the same recessive disease allele(s) [2].

\section{Discussion}

The results of the 2005 Iran Low Fertility Survey [25] demonstrate a number of significant changes associated with the practice of consanguineous marriage that would be expected to impact significantly both on the demographic structure of the population and on the disease burden imposed by inherited disorders. 


\section{The Decreasing Prevalence of Consanguineous}

\section{Marriages in Iran}

There has been a significant overall reduction in the prevalence of consanguineous marriages in Iran since the mid-1980s, with varying rates of change in different locations within the country, reflecting factors such as domicile, levels of female education, and marital preferences (table 2). Given the significant decline in family sizes over the same period, and a concomitant reduction in the numbers of cousins who are of marriageable age, it is highly probable that the general pattern of a reduction in the prevalence of consanguineous marriages will continue into future generations. However, in view of the long tradition of consanguineous marriage in Iran and its importance in the maintenance of land-holdings, the rate at which this decline will occur is open to question, especially in the populations of more conservative rural areas [35]. Furthermore, in those parts of the country which continue to experience civil unrest, such as Sistan-Baluchistan, a decline in consanguinity is improbable, since close-kin marriage is regarded as a beneficial means of safeguarding personal and family security [36].

\section{Consanguinity and Fertility}

Some fertility issues are primarily artefactual in nature, for example, the apparent temporal increase in the proportion of pregnancies that fail to result in a live birth (table 3). Prenatal losses have often been significantly underestimated, because women who were unaware of their pregnancy had miscarried and/or due to problems in the recall of prenatal losses $[37,38]$. The present study almost certainly mirrors these earlier findings, with the unintentional failure by mothers to acknowledge all of their past pregnancy losses, especially spontaneous abortions early in pregnancy or losses which had occurred in previous decades [2,39].

The larger mean number of pregnancies initiated by women married to a consanguineous spouse (fig. 3) may similarly be a more complex issue than assumed at first. For example, the lower mean age at marriage of consanguineous parents offers an enhanced opportunity to initiate child-bearing at younger ages. There is also evidence that, on average, women in consanguineous relationships continue child-bearing to comparatively later ages [40], thus extending their reproductive span. These findings could reflect their more rural background and lower mean level of education (table 2), and may also be indicative of restricted access to, and lesser use of, reliable methods of contraception [41].

\section{Consanguinity, Postnatal Mortality and the}

Prevalence of Genetic Disease(s)

In a country such as Iran, with a long tradition of consanguineous marriage, it is highly probable that the mean coefficient of inbreeding calculated for the present generation $(\alpha=0.0149)$ significantly underestimates the $\mathrm{cu}-$ mulative levels of consanguinity in the 4 study populations. When close-kin unions have been contracted in successive generations, the resultant level of genomic homozygosity significantly exceeds the calculated value [42].

From a genetic perspective, the first and possibly most important influence of a shift away from consanguineous marriage would be on the overall incidence of genetic disease(s) in the Iranian population. In Western countries with an underlying low level of close-kin marriage, it has been demonstrated that a decline in consanguinity and/or community endogamy results in a reduction in homozygosity [43], with a consequent reduction in the numbers of people whose health is adversely affected by disorders caused by the expression of recessive disease genes [44]. However, as a multi-ethnic society, the influence of population stratification is highly probable in Iran, with many founder mutations concentrated within or even unique to specific communities [45]. Given this scenario, unless the shift from consanguinity is accompanied by a decline in intra-community endogamy, the rate at which recessive disorders reduce in prevalence may be significantly slower than expected $[1,45,46]$.

The early death of a child has been shown to enhance the probability of a more rapid subsequent conception and live birth [39, 47]. In the case of death ascribed to recessive gene expression, besides increasing the numbers of subsequent births, reproductive compensation effectively reduces the rate at which recessive disease alleles are eliminated from the gene pool [48-50]. But even allowing for continuing marital endogamy and reproductive compensation, the marked reduction in mean family sizes that has occurred in Iran since the 1980s (fig. 2, 3) should result in a significant overall reduction in the numbers of people who are born with a recessive genetic disease, including complex disorders with a recessive gene component [1].

In proportional terms, the effect of these various changes would predictably be greatest for diseases encoded by rare mutations, e.g. primary immunodeficiencies resulting in increased susceptibility to infectious disease(s) $[51,52]$, or chronic childhood kidney disorders $[53,54]$. However, in terms of absolute numbers, recessive disorders that are common and not restricted to any single
Hosseini-Chavoshi/Abbasi-Shavazi/ Bittles 
community, such as non-syndromic hearing impairment $[55,56]$ and intellectual and developmental disabilities $[57,58]$, should show the most obvious future decline in prevalence.

\section{Premarital Testing, Prenatal Diagnosis and Medical}

Termination of Pregnancy

Under a scheme jointly administered by the Ministry of Health and the Governmental Marriage and Divorce Registration Offices, all couples intending to marry in Iran are required to undergo prior testing for drug addiction, $\beta$-thalassaemia and sexually transmitted diseases. On receipt of the test results, the couple is then expected to undertake a training session on family planning and on reproductive and family health issues, which includes advice on possible inherited disorders and the option of seeking genetic counselling where there is a family history of disease.

While pregnancy termination to save the mother's life has historically been permitted within Islam [59], abortion was otherwise prohibited. This situation changed within the majority Shia branch of Islam in Iran with the issue of a Fatwa in 1997, permitting the therapeutic abortion of the fetus prior to their ensoulment at 20 weeks' gestation. The ruling was subsequently approved by the Iranian Parliament in 2003 and by the Islamic Guardian Council in 2005 but under specifically defined circumstances [59].

It has been estimated that some 2.0 million Iranians carry a mutation for the recessive haemoglobinopathy $\beta$-thalassaemia [60], with $52 \beta$-globin chain mutations identified to date [61]. Initially, permission for the medical termination of pregnancy was allowed for this disorder alone. However, under the terms of the 2005 Islamic Guardian Council legislation, a list of some additional 19 maternal and 24 fetal categories of disease was compiled for which termination was permitted prior to the 20th week of gestation [59], with the possibility that additional genetic disorders could be included in the future [62].

The passage of the 2005 legislation has radically changed the balance of approval for a medical termination of pregnancy within Iran, from a pattern of predominantly maternal health concerns to disorders which affect the viability or well-being of the fetus and the probability of a healthy future life [62]. A recent study has, however, shown that a majority of pregnancies were not terminated in cases of genetic disorders, either because the disorder had not been diagnosed or an application for a termination had not been lodged before the stipulated 20 week limit [63]. In addition, a small minority of clinicians [64] and the parents of children with a genetic disorder [65] regarded even the early termination of pregnancy as unacceptable on personal, religious grounds.

Notwithstanding these legal and personal issues, it seems inevitable that, as elsewhere, the overall burden of genetic disease(s) in Iran will be reduced due to a combination of major declines in the prevalence of consanguineous marriages and in completed family sizes, genetic counselling, premarital and prenatal screening programmes for the prevention of common, inherited disorders, such as $\beta$-thalassaemia $[66,67]$, and the possibility of medical termination of pregnancy. Against this background, calls for legal interventions to restrict consanguineous marriage are inappropriate and any attempt to introduce and enforce such a ban could well prove to be socially counter-productive [68]. An expansion of the existing health services within the public sector, with improved accessibility to genetic counselling and the inclusion of neonatal screening and specialist diagnostic and treatment facilities for genetic disorders, is therefore likely to be a more constructive and acceptable approach. Especially if organized at community level [69], complemented by genetic education programs provided at secondary and tertiary education levels, and made available to the general public via the mass media and online.

\section{References}

1 Bittles AH, Black ML: Consanguinity, human evolution and complex diseases. Proc Natl Acad Sci USA 2010;107:1779-1786.

2 Bittles AH: Consanguinity in Context. Cambridge, Cambridge University Press, 2012.

3 Farhud DD, Mahmoudi M, Kamali MS, Marzban M, Andonian L, Saffari R: Consanguinity in Iran. Iran J Public Health 1991;20:1-15.

4 Ketabi A: Marriage with close relatives in ancient Iran (in Persian). J Soc Sci 2000;16:167192.
5 Akrami SM, Osati Z: Is consanguineous marriage religiously encouraged? Islamic and Iranian considerations. J Biosoc Sci 2007;39: 313-316.

6 Saadat, M: Consanguineous marriages in Iranian folktales. Commun Genet 2007;10:3840.

7 Bittles AH, Black ML: Global patterns and tables of consanguinity, 2013. http://consang. net.
8 Khlat M: Consanguineous marriages in Beirut: time trends, spatial distribution. Soc Biol 1985;35:324-330.

9 al-Abdulkareem AA, Ballal MD: Consanguineous marriage in an urban area of Saudi Arabia: rates and adverse health effects on the offspring. J Community Health 1998;23:7583.

10 Radavanovic Z, Shah N, Behbehahi J: Prevalence and social correlates of consanguinity in Kuwait. Ann Saudi Med 1999;19:206-210.
Reproductive and Health Outcomes of Consanguinity in Iran 
11 Hamamy H, Jamhawi L, Al-Darawsheh J, 28 Abbasi-Shavazi MJ, Askari-Nodoushan A, Ajlouni K: Consanguineous marriages in Jordan: why is the rate changing with time? Clin Genet 2005;76:511-516.

12 Assaf S, Khawaja M: Consanguinity trends and correlates in the Palestinian Territories. J Biosoc Sci 2009;41:107-124.

13 Rajaee F (ed): The Iran-Iraq War: The Politics of Aggression. Gainesville, University Press of Florida, 1993.

14 Givens BP, Hirschman C: Modernization and consanguineous marriages in Iran. J Marriage Fam 1994;56:820-834.

-15 Akrami SM, Montazeri V, Shomali SR, Heshmat R, Larijani B: Is there a significant trend of consanguineous marriage in Tehran? A review of three generations. J Genet Couns 2009; 18: 82-86.

16 Abbasi-Shavazi MJ, McDonald P, HosseiniChavoshi M: Modernization or cultural maintenance: the practice of consanguineous marriage in Iran. J Biosoc Sci 2008;40:911933.

17 Farhud DD, Kamali MS, Walizadeh GH, Kamali Rusta M: Some biological data on the Iranian infants. South Asian Anthropol 1991;12: 33-37.

18 Saadat M, Ansari-Lari M, Farhud DD: Consanguineous marriage in Iran. Ann Hum Biol 2004;31:263-269.

19 Abbasi-Shavazi MJ, Sadeghi R: Ethnicity and family patterns in Iran (in Persian). Pazhuhisi zanan 2005;3:25-47.

20 Abbasi-Shavazi MJ, McDonald P, HosseiniChavoshi M: The Fertility Transition in Iran: Revolution and Reproduction. Dordrecht, Springer, 2009.

21 Statistical Center of Iran: Selected findings of the 2011 National Population and Housing Census. Tehran, Statistical Center of Iran, 2011. http://www.amar.org.ir/Portals/1/Iran/ 90.pdf/.

22 Iran Ministry of Health and Medical Education: Islamic Republic of Iran's Multiple Indicator Demographic and Health Survey. Tehran, Ministry of Health and Medical Education, 2010.

23 Christianson A, Howson CP, Modell B: March of Dimes Global Report on Birth Defects. White Plains, March of Dimes Birth Defects Foundation, 2006.

24 PRB: Population Data Sheet. Washington, Population Reference Bureau, 2012.

25 Hosseini-Chavoshi M, McDonald P, AbbasiShavazi MJ: Fertility and Contraceptive Use Dynamics in Iran: Special Focus on Low Fertility Regions. Australian Demographic and Social Research Institute, Working Paper No. 1. Canberra, Australian National University, 2007.

-26 Al-Gazali LI, Bener A, Abdulrazzaq YM, Micallef R, Al-Khayat AI, Gaber T: Consanguineous marriages in the United Arab Emirates. J Biosoc Sci 1997;29:491-497.

$\checkmark 27$ Bener A, Alali KA: Consanguineous marriage in a newly developed country: the Qatari population. J Biosoc Sci 2006;38:239-246.
Thornton A: Family life and developmental idealism in Yazd, Iran. Demogr Res 2012;26: 207-238.

29 Al-Mazrou YY, Fraid SM, Khan MU: Changing marriage age and consanguineous marriage in Saudi females. Ann Saudi Med 1995 15:481-485.

30 Hussain R: Community perceptions of reasons for preference for consanguineous marriages in Pakistan. J Biosoc Sci 1999;31:449461.

31 Hamamy H, Bittles AH: Genetic clinics in Arab countries: meeting individual, family and community needs. Public Health Genomics 2009;12:30-40.

32 Al-Thakeb FT: The Arab family and modernity: evidence from Kuwait. Curr Anthropol 1985;26:575-580

33 Khlat M: Consanguineous marriage and reproduction in Beirut, Lebanon. Am J Hum Genet 1988;43:188-196.

34 Jurdi R, Saxena PC: The prevalence and correlates of consanguineous marriages in Yemen: similarities and contrasts with other Arab countries. J Biosoc Sci 2003;35:1-13.

- 35 Fathzadeh M, Bigi MAB, Bazrgar M, Yavarian M, Tabatabace HR, Akrami SM: Genetic counseling in Southern Iran: consanguinity and reason for referral. J Genet Counsel 2008; 17:472-479.

-36 Sthanadar AA, Bittles AH, Zahid M: Civil unrest and the current profile of consanguineous marriage in Khyber Pakhtunkhwa Province, Pakistan. J Biosoc Sci 2013, DOI: 10.1017/ 500219320013000552.

-37 Wilcox AJ, Horney LF: Accuracy of spontaneous abortion recall. Am J Epidemiol 1984;120: 727-733.

38 Wilcox AJ, Weinberg CR, O'Connor JF, Baird DD, Schlatterer JP, Canfield RE, Armstrong EG, Nisula BC: Incidence of early loss of pregnancy. New Engl J Med 1988;319:189-194.

39 Bittles AH, Grant JC, Sullivan SG, Hussain R: Does inbreeding lead to decreased human infertility? Ann Hum Biol 2002;29: 111-131.

-40 Tunçbílek E, Koc I: Consanguineous marriage in Turkey and its impact on fertility and mortality. Ann Hum Genet 1994;58:321-329.

41 Hussain R, Bittles AH: Consanguinity and differentials in age at marriage, contraceptive use and fertility in Pakistan. J Biosoc Sci 1999; 31:121-138.

42 Bittles AH: Consanguinity, genetic drift and genetic diseases in populations with reduced numbers of founders; in Speicher M, Antonarakis SE, Motulsky AG (eds): Human Genetics - Principles and Approaches, ed 4. Heidelberg, Springer, 2009, pp 507-528.

43 Nalls MA, Simon-Sanchez J, Gibbs JR, PaisonRuiz C, Bras JT, Tanaka T, Matarin M, Scholz S, Weitz C, Harris TB, Ferrucci L, Hardy J, Singleton AB: Measures of autozygosity in decline: globalization, urbanization, and its implications for medical genetics. PLoS Genet 2009;5:e1000415.
44 Campbell H, Rudan I, Bittles AH, Wright AF: Human population structure, outbreeding and human health. Genome Med 2009;11:91.

45 Bittles AH: A community genetics perspective on consanguineous marriage. Community Genet 2008;11:324-330

46 Overall ADJ: The influence of the Wahlund effect on the consanguinity hypothesis: consequences for recessive disease incidence in a socially structured Pakistani population. Hum Hered 2009;67:140-144.

-47 Skjærven R, Wilcox AJ, Lie RT, Irgens LM Selective fertility and the distortion of perinatal mortality. Am J Epidemiol 1988;128:13521363.

-48 Schull WJ, Furusho T, Yamamoto M, Nagano $\mathrm{H}$, Komatsu I: The effect of parental consanguinity and inbreeding in Hirado, Japan. IV. Fertility and reproductive compensation. $\mathrm{Hu}$ mangenetik 1970;9:294-315

49 Schull WJ, Neel JV: The effects of parental consanguinity and inbreeding in Hirado, Japan. V. Summary and interpretation. Am Hum Genet 1972;24:425-453.

50 Overall ADJ, Ahmad M, Nichols RA: The effect of reproductive compensation on recessive disorders within consanguineous human populations. Heredity 2002;88:474-479.

51 Rezaei N, Pourpak Z, Aghamohammadi A, et al: Consanguinity in primary immunodeficiency disorders; the report from Iranian Primary Immunodeficiency Registry. Am J Reprod Immunol 2006;56:145-151.

52 Aghamohammadi A, Moin M, Rezaei N: History of primary immunodeficiency diseases in Iran. Iran J Pediatr 2010;20:16-34.

53 Madani K, Otoukesh H, Rastegar A, Van Why S: Chronic renal failure in Iranian children. Pediatr Nephrol 2001;16:140-144.

54 Gheissari A, Kelishadi R, Roomizadeh P, Abedini A, Haghjooy-Javanmard S, Abtahi SH, Mehdikhani B, Shafiei M: Chronic kidney disease stages 3-5 in Iranian children: need for a school-based screening strategy: the CASPIAN-III study. Int J Prev Med 2013;4:95-101.

55 Babanejad M, Fattahi Z, Bazazzadegan N, Nishimura C, Meyer N, Nikzat N, Sohrabi E, Najmabadi A, Jamali P, Habibi F, Smith RJ, Kahrizi K, Najmabadi H: A comprehensive study to determine heterogeneity of autosomal recessive nonsyndromic hearing loss in Iran. Am J Med Genet A 2012;158A:24852492.

56 Bazazzadegan N, Nikzat N, Fattahi Z, et al: The spectrum of GJB2 mutations in the Iranian population with non-syndromic hearing loss - a twelve year study. Int J Pediatr Otorhinolaryngol 2012;76:1164-1174.

-57 Najmabadi H, Motazacher MM, Garshasbi $\mathrm{M}$, et al: Homozygosity mapping in consanguineous families reveals extreme heterogeneity of non-syndromic autosomal recessive mental retardation and identifies 8 novel gene loci. Hum Genet 2007;121:43-48.

58 Najmabadi H, Hu H, Garshasbi M, et al: Deep sequencing reveals 50 novel genes for recessive cognitive disorders. Nature 2011;478:57-63. 
59 Hedayat KM, Shooshtarizadeh P, Raza M: Therapeutic abortion in Islam: contemporary views of Muslim Shiite scholars and effect of recent Iranian legislation. J Med Ethics 2006; 32:652-657.

60 Najmabadi H, Karimi-Nejad R, Sahebjam S, Poufarzad F, Teimourian S, Sahebjam F, Amirizadeh N, Karimi-Nejad MH: The beta-thalassemia mutation spectrum in the Iranian population. Hemoglobin 2001;25:285-296.

61 Rahimi Z: Genetic epidemiology, hematological and clinical features of hemoglobinopathies in Iran. Biomed Res Int 2013;2013: 803487.
62 Bazmi S, Behnoush B, Kiani M, Bazmi E: Comparative study of therapeutic abortion permissions in Central Department of Tehran Legal Medicine Organization before and after approval of law on abortion in Iran. Iran J Pediatr 2008; 18:315-322.

63 Samadirad B, Khamnian Z, Hosseini MB, Dastgiri S: Congenital anomalies and termination of pregnancy in Iran. J Pregnancy 2012;2012:574513.

64 Karimi M, Bonyadi M, Galehdari MR, Zareifar S: Termination of pregnancy due to thalassaemia major, haemophilia, and Down's syndrome: the view of Iranian physicians. BMC Med Ethics 2008;9:19.

65 Karimi M, Johari S, Cohan N: Attitude towards prenatal diagnosis for beta-thalassemia major and medical abortion in Southern Iran. Hemoglobin 2010;34:49-54.
66 Samavat A, Modell B: Iranian national thalassaemia screening programme. BMJ 2004; 329:1134-1137.

67 Zeinalian M, Nobari RF, Moafi A, Salehi M, Hashemzadeh-Chaleshtori M: Two decades of pre-marital screening for beta-thalassemia in central Iran. J Community Genet 2013;4: 517-522.

68 Hamamy H, Antonarakis SE, Cavalli-Sforza LL, et al: Consanguineous marriages: pearls and perils: Geneva International Consanguinity Workshop Report. Genet Med 2010; 13:841-847.

69 Barzandeh SA, Behsid M, Hosseini MB, Ezari M, Taghizadeh M, Dastgiri S: Community genetic services in Iran. Genet Res Int 2012; 2012:129575. 